\title{
ПСИХОЛОГІЧНІ ЗАСАДИ БУЛІНГУ \\ В ЮНАЦЬКОМУ ВІЦІ
}

УДК: 159.98.616.89-008.444.9

\section{Гончарук Наталія Миколаӥвна}

Кандидат психологічних наук, доцент, доиент кафедри загальної та практичної психологї, Кам'янець-Подільський національний університет імені Івана Огієнка, м. Кам'янеиьПодільський (Украӥна)

ORCID ID: https://orcid.org/0000-0001-9552-0946 Researcher ID: F-8043-2018

\section{Онуфрієва Ліана Анатолївна}

Кандидат психологічних наук, доцент, професор кафедри, завідувач кафедри загальної та практичної психології, Кам'янець-Подільський національний університет імені Івана Огієнка, м. Кам'янець-Подільський (Украӥна)

ORCID ID: http://orcid.org/0000-0003-2442-4601 Researcher ID: R-5598-2018

Анотація. У статті висвітлено проблему булінгу в середовищі старшокласників. Зазначено, щзо ефективна комунікація є важливим і невід'ємним аспектом життя школярів. Актуальність проблеми підтверджується статистичними даними, адже на сьогодні Україна посідає 4 місие в Свропі щุодо поширення проблеми булінгу, а в школах 45,3\% дітей були жертвами булінгу і 42,2\% самі ж його провокували, свідчить про те, щчо проблема булінгу $\epsilon$ назрілою та актуальною. Авторами описано підходи до пояснення ичього явища як психологічного феномену. Виокремлено форми та різновиди булінгу. Розкрито основні його характеристики як системного концепту, який охоплює психологічний, фізичний та інші види спрямованого агресивного впливу. Під час емпіричного дослідження визначено характеристики, які уможливлюють вивчити різні сторони вказаної психологічної проблеми. Зокрема, опрацьовано інформаційно-змістовий та структурно-позиційний ї̈ аспекти та доведено необхідність розроблення диференційованого підходу до подолання булінгу як різнопланової форми дитячого насилля. 
За результатами дослідження акцентовано увагу на найбільи актуальних питаннях, якими є завдання посиленого психолого-педагогічного контролю за поведінкою та умовами розвитку школярів, формування навичок конструктивної комунікації в середовищі однолітків $i$ дитячо-батьківської взаємодї у кризових ситуаціях. Детальний аналіз показує, щчо у школярів не сформовані навички конструктивної взаємодї та вміння реагувати в кризових ситуаціях. Виходячи з того, щуо самостійно цуі навички не формуються, а в украӥнських школах не введено дисциплін з психології комунікації, доцільно було би додати до шкільної програми обов'язковий курс, орієнтований на формування комунікативних навичок у різних сферах життя та діяльності, щзо стосуються спілкування з однолітками, ділової комунікаџії з вчителями та іншими дорослими, сімейного спілкування у родині, а також конструктивних вмінь будувати комунікацію у кризових ситуаціях, використовуючи норм етичної взаємодії.

Ключові слова: булінг, булер, агресор, жертва булінгу, форми булінгу.

Постановка проблеми. Зростання теоретичного інтересу до дослідження агресії та булінгу зумовлено тим, що перехідні, кризові періоди трансформації соціальних систем завжди пов’язані зі зростанням негативних таких явищ. Трансформація нашого суспільства пов’язана із перебудовою особистості і свідомості, $з$ переоцінкою цілої низки особистіснопсихологічних якостей. Зокрема, це стосується також переоцінки ролі і місця агресії та булінгу в розвитку особистості в рамках системи освіти.

Збільшена кількість випадків прояву булінгу є однією із найбільш гострих проблем не лише для лікарів, педагогів і психологів, але і для суспільства загалом. Актуальність теми безперечна, оскільки число підлітків і молоді із такою поведінкою нестримно зростає, що викликано наявністю багатьох несприятливих чинників, а саме: погіршенням соціальних умов життя; кризою родинного виховання; неувагою навчального закладу до нер- вово-психічного стану; збільшенням долі патологічних пологів, що залишають наслідки у вигляді пошкоджень головного мозку дитини. Свій внесок роблять також засоби масової інформації, кіно- і відеоіндустрія, соціальні мережі, де регулярно демонструється та пропагується культ насильства, приниження, образ, цькування і знущання, ін.

Останніми роками науковий інтерес до проблеми булінгу істотно зріс, але, нажаль, роботи переважно наповнені теоретичними міркуваннями про іiї механізми і прояви. Водночас досліджень, заснованих на реальному досвіді корекції і терапії, відносно небагато. Тим часом, особливо важливою $є$ допомога тим особам, прояви булінгу в яких знаходяться лише у стадії становлення, що дозволяє зробити своєчасні корегуючі заходи і створити захисні механізми.

$$
3 \text { точки зору структурно- }
$$
функціональної організації психологічних захисних механізмів цю проблему розглядали 
Ф. Бассін, М. Бурлакова, В. Волков, Т. Горобець, Ю. Савенко, О. Соколова, Л. Субботіна. Генезис та функціонування психологічного захисту досліджували Є. Романова, Л. Гребенніков, Р. Грановська, І. Нікольска, В. Менінжер, М. Ліф, А. Налчаджян, Г. Тарт. Порівняльні дослідження біологічних і психологічних їх компонентів здійснено Т. Арістовою. Адаптивний потенціал психологічного захисту досліджували I. Антоненко, Є. Романова, Л. Гребенніков [2]. Психоаналітичні розробки механізмів психологічного захисту проводили Ж. Бержере, Е. Берн, А. Фрейд, 3. Фрейд. На переконання науковців, найбільш дослідженими на сьогодні $є$ такі механізми психологічного захисту як заперечення, витіснення, проекція, ідентифікація, раціоналізація, заміщення, відчуження [2; 13; 14]. Механізми відпрацювання психологічного захисту досліджували Ж. Лапланш, Ж.Б. Понталіс. Засоби експлікації та утилізації захисних механізмів аналізували С. В. Карпенко, В. Логвиненко [2]. Вплив патернів психологічного захисту на нормалізацію труднощів спілкування досліджували Л. Анциферова, Ф. Василюк, Ю. Кузіна, Р. Набіулліна, О. Руськіна, I. Тухтарова. 3 точки зору дослідників, відпрацювання механізмів психологічного захисту має полягати в їньому самоусвідомленні, цілемотиваційній спрямованості, самоорганізації, саморегуляції, посиленні відповідальності особистості, переосмисленні наявного досвіду для формування ефективних захисних моделей поведінки [2].

3 досвіду психологічної роботи [2], у загальноосвітніх навчальних закладах на сьогоднішній день не приділяється належна увага формуванню ефективної системи психологічного захисту в умовах спілкування. Саме у цьому віці необхідно формувати навички спілкування та, відповідно систему захисної комунікативної поведінки у складних ситуаціях стресу, тривоги, насилля, булінгу та фрустрації. Виникає необхідність у проведенні спеціальних обстежень, спрямованих на виявлення особливостей функціонування психологічних захисних механізмів цієї вікової категорії дітей, розробку корекційних методів і прийомів роботи, які б сприяли формуванню позитивного досвіду спілкування, що уможливить необхідні умови для адаптації до життя у соціумі, уникаючи проявів булінгу, насилля та агресії [2].

\section{Аналіз останніх наукових дослі-}

джень. Одним із пріоритетних принципів державної політики у галузі навчально-виховної діяльності, викладеного у законі України «Про освіту», є виховання поваги до прав i свобод дитини, з одного боку, та нетерпимості до приниження, насильства, дискримінації, з іншого. Водночас, практичні психологи освітніх закладів усіх рівнів час від часу зустрічаються 3 проблемою спрямованого насильства, одним із різновидів якого є булінг [6, с. 5]. Інтерес до проблеми булінгу набуває особливої актуальності у зв'язку з набуттям чинності 
Закону України від 18.12.2019 року № 2657VIII «Про внесення змін до деяких законодавчих актів України щодо протидії булінгу (цькуванню)», в якому викладено посилені вимоги щодо запобігання та усунення випадків насильства у закладах освіти [7, с. 9].

Булінг у психологічній інтерпретації означає систематичні переслідування особою чи групою осіб, що супроводжуються цькуванням, приниженням, залякуванням. Розуміння цього явища у психології є різноплановим.

Українськими та зарубіжними вченими впродовж останніх років розроблено й практично апробовано низку наукових концептів щодо подолання проблеми булінгу в шкільному середовищі. Зокрема, соціально-психологічні підходи до цієї проблеми розроблено науковцями А. Губко [3], Д. Лейном [4], І. Сидорук [6]. Оцінку ознак та форм булінгу здійснено дослідниками P. Randall [11], M. Perillo [12]. Питання протидії та подолання булінгу в дитячому середовищі опрацьовано психологами О. Шевченко [9], Л. Вольновою [1]. Проте, дослідження проблеми булінгу перебуває на етапі становлення, тому виникає багато питань, які потрібно опрацювати і розв'язати.

Одні дослідники описують його як несприятливий зовнішній соціальний вплив, процес, явище, ситуацію: булінг - це специфічна соціальна ситуація, яка виникає у групі та базується на порушених соціальних стосунках зі специфічною груповою динамікою
(А. А. Губко [3, с. 49]); явище, що формується у колективах і впливає на всіх його учасників, призводячи до порушення навчальновиховного процесу та породжуючи несприятливі наслідки для особистості (I. Сидорук [6, c.172]); довготривалий процес усвідомленого жорстокого поводження членів групи по відношенню до окремої особи, котра не здатна себе захистити (Д. А. Лейн [4, с. 240]).

Друга частина науковців акцентує увагу на агресивному ставленні до об'єкта булінгу як потенційної жертви й описує це явище як знущання, спрямовану агресію або переслідування: булінг - це навмисне знущання фізичним, вербальним або психологічним способом (О. О. Шевченко [9, с.49]); неочікувана агресивна поведінка, яка передбачає дисбаланс влади і повторюється з часом [9]; насильство, що вчиняється стосовно потерпілого, що призводить до заподіяння шкоди його психічному або фізичному здоров'ю [8, с. 9].

Третя група вчених пояснює булінг як проблемну конфліктну взаємодію, яка характеризується несформованістю вмінь та навичок конструктивної комунікації: булінг - це соціальна взаємодія, через яку одна особа зазнає нападів з боку інших осіб впродовж тривалого період, що зумовлює у неї стан безпомічності та відторгнутості (P. Randall [11]); несприятлива соціальна взаємодія, основою якої $€$ приниження та залякування (M. Perillo [12]).

За результатами цього аналізу можна 
визначити три основні характеристики булінгу як системного явища: 1) несформованість соціальної ситуації розвитку групи, що проявляється у порушенні групової динаміки та стійкому статусно-рольовому протистоянні; 2) наявність спрямованого агресивного ставлення, що відповідним чином характеризує атмосферу взаємин у групі; 3) порушення групової комунікації, що призводить до міжособистісних конфліктів.

Теоретичний аналіз наукових джерел уможливлює виявити та оцінити найбільш важливі ознаки булінгу. Їх виділено у групи за змістовими характеристиками [1]: 1-а група - статусний дисбаланс (дисбаланс влади): популярні діти знущаються над малопопулярними, сильні над слабкими; 2-а група - групове відторгнення: жертва булінгу стає ізольованою або відторгнутою у колективі однолітків; дружити 3 нею у групі вважається непрестижним і ганебним; 3-я група - мотивація нанесення шкоди: в одногрупників виникає стійкий і неухильний намір нашкодити; спостерігається прагнення викликати емоційний або фізичний біль у потерпілого; 4-а група наявність емоційного задоволення від страждань жертви: кривдник насолоджується, спостерігаючи як об'єкт насилля потерпає від знущань; 5-а група - системність повторень: наруга та знущання мають тенденцію до повторення; і кожного разу вони проявляються у різних, більш досконалих формах, таких як цькуванні, глузуванні, фізичній агресії, групо- вому бойкоті; 6-а група - загроза подальшої агресії: жертва усвідомлює, що терор буде продовжуватись і це призводить до наступних нервових зривів [1].

Описані групи ознак розкриваються нерівномірно і диференційовано, проявляючись у різновидах та формах булінгу. Як засвідчує аналіз теоретичних джерел, більшість вчених акцентують увагу на двох, найбільш актуальних формах: 1) фізичному булінгу побоях, стусанах, знівеченнях, щипаннях, сексуальних діях; 2) психологічному - словесних образах, погрозах, залякуванні, шантажі, кібермобінгу (за I. Сидорук [6, с.170]).

Мета статті - здійснити психологічний аналіз проблеми булінгу у шкільному середовищі серед дітей юнацького віку.

Методика та організація дослідження. Для реалізації цієї мети підготовлено програму дослідження, яка включає теоретикометодологічні підходи та експериментальні методи. Серед теоретичних підходів - аналіз наукових джерел з проблеми, систематизація, структурування, узагальнення отриманих результатів. Експериментальним методом визначено анкетування 3 використанням опитувальної програми «Булінг у шкільному середовищі».

Виклад основного матеріалу та результати дослідження. У Законі України «Про внесення змін до деяких законодавчих актів України щодо протидії булінгу (цькуванню)» окрім психологічного та фізич- 
ного виділено ще 2 форми боулінгу - економічний та сексуальний. Економічним булінгом вважається навмисне нанесення шкоди або силове вилучення майна жертви. Сексуальний булінг полягає у застосуванні сексуальних домагань, розповсюдженні відвертих відео та інших діях інтимного характеру [8, c. 9].

У доповнення до цього в наукових розвідках вивчається кібер-булінг (або інтернетмобінг), що полягає у цькуванні опонентів через Інтернет-мережу [5].

На офіційному сайті протидії булінгу у Сполучених Штатах Америки подано свою, автентичну класифікацію, за якою визначено три різновиди булінгу: словесні знущання, реляційне залякування, фізична агресія.

Словесними знущаннями, спрямованими на завдання психічного насилля, найчастіше виступають образи, погрози, прізвиська, сексуальні коментарі. До реляційних залякувань, які наносять шкоду репутації, відносять ізоляцію, виключення із спільної діяльності колективу, публічні принизливі зауваження, розповсюдження чуток, прямі вказівки щодо вибору друзів. Фізичне знущання, яке передбачає силові форми впливу, передбачає нанесення тілесних пошкоджень, відштовхування, кидання речей у співрозмовника, збивання 3 ніг [10].

Вивчення проблеми булінгу потребує детального аналізу її ознак та змістових характеристик, що здійснюється у межах інформа- ційно-змістового аспекту дослідження.

Дослідження проводилось восени 2018 року серед осіб юнацького віку загальноосвітніх шкіл міста Кам'янець-Подільський. Вибірка склала 128 осіб. Для цього було проведено анкетування осіб юнацького віку, яке передбачало такі запитання:

1. Чи знайомі ви з проблемою булінгу? (так; ні)

2. Що ви вважаєте булінгом?

3. Чи були ви колись об'єктом булінгу? (так; ні).

4. Які прояви булінгу було застосовано щодо вас (фізичну агресію (побиття, штовхання, ...); словесні напади та знущання; залякування; відторгнення однолітками; приниження гідності педагогами перед класом; сексуальні домагання, відбирання речей; усі перераховані різновиди).

5. Хто проявляв подібне ставлення до вас? (батько; мати; однолітки чи старші діти; педагоги, незнайомі люди у громадських місцях, інше).

6. Що ви відчували у ситуації булінгу? (образу; біль; ненависть до кривдника; бажання помститися; власну слабкість; зневіру; страх, інше).

7. Хто захищав вас у таких ситуаціях? (батьки, педагоги, друзі, ніхто).

8. Чи ви самі коли-небудь принижували інших? (так; ні).

9. Що провокувало вас на таке ставлен- 
ня? (слабкість товариша; його неадекватна поведінка, ..., інше).

10. Чи були ви спостерігачем цькувань та принижень ваших однолітків?

11. Якою була ваша позиція у цих ситуаціях? (невтручання, захист жертви від нападників, допомога агресору, інше).

12. Хто із дорослих розповідав вам про булінг та шляхи його подолання?

Результати дослідження продемонстрували, що із 128 осіб, котрих було залучено до анонімного анкетування, лише 106 (82,8\%) були ознайомлені із наявністю такої проблеми у суспільстві. Решта 22 (17,2\%) вперше зустрілись 3 цим терміном. Як продемонстрували результати дослідження, 68 осіб $(53,1 \%)$ отримали інформацію про проблему булінгу від педагогів, 26 (20,3\%) - від практичних психологів, 12 (9,4\%) - від батьків, решта - 3 інших

(35,9\%) насилля. На їхню думку, психологічний булінг полягає у використанні спрямованого впливу на почуття та свідомість 3 використанням словесних образ, прізвиськ, погроз, залякувань, шантажу. Він завдає моральної шкоди та залишає душевні шрами у дитячій психіці. Інтегрований включає різні форми насилля, у тому числі фізичне, економічне, сексуальне, кібер-агресію. Найрідше діти схильні вважати булінгом економічні $(3,1 \%)$ та сексуальні $(3,1 \%)$ форми насилля. Це пов'язано $з$ тим, що вони не $є$ характерними у віковому та етичному аспекті і менше всього зустрічаються в умовах школи. Школярі в українських школах не схильні надавати пріоритет відвертим крадіжкам та діям 3 пошкодження чи відбирання особистих речей жертви, а також сексуальним домаганням, що передбачають сексуальне насилля. Диференційний розподіл відповідей школярів можна проаналізу-

Таблиия 1.

\section{Форми насилля, які школярі вважають булінгом}

\begin{tabular}{|c|c|c|c|c|c|}
\hline $\begin{array}{l}\text { Ознаки } \\
\text { булінгу }\end{array}$ & $\begin{array}{c}\text { Моральне прини- } \\
\text { ження, цьку- } \\
\text { вання, знущання, } \\
\text { залякування чи } \\
\text { шантаж } \\
\end{array}$ & $\begin{array}{c}\text { Побиття та } \\
\text { інші види фі- } \\
\text { зичного на- } \\
\text { силля }\end{array}$ & $\begin{array}{c}\text { Пошкоджен- } \\
\text { ня чи відби- } \\
\text { рання особи- } \\
\text { стих речей } \\
\text { жертви }\end{array}$ & $\begin{array}{l}\text { Сексуальні до- } \\
\text { магання, } \\
\text { розповсюджен- } \\
\text { ня відвертих } \\
\text { відео }\end{array}$ & $\begin{array}{c}\text { Різні фор- } \\
\text { ми знущан- } \\
\text { ня }\end{array}$ \\
\hline $\begin{array}{l}\text { Форми } \\
\text { булінгу } \\
\end{array}$ & Психологічна & Фізична & Економічна & Сексуальна & Інтегрована \\
\hline $\begin{array}{c}\text { К-ть осіб } \\
(\text { y\%) }\end{array}$ & $51,6 \%$ & $6,3 \%$ & $3,1 \%$ & $3,1 \%$ & $35,9 \%$ \\
\hline
\end{tabular}

джерел або не отримали взагалі (див. Табл. 1).

Дані таблиці свідчать, що найбільше школярі схильні вважати булінгом психологічне насилля $(51,6 \%)$ або інтегровані види вати за Рис. 1.

Аналіз діаграми засвідчує, що найчастіше термін «булінг» школярі відносять до психологічних форми впливу, які полягають у мо- 


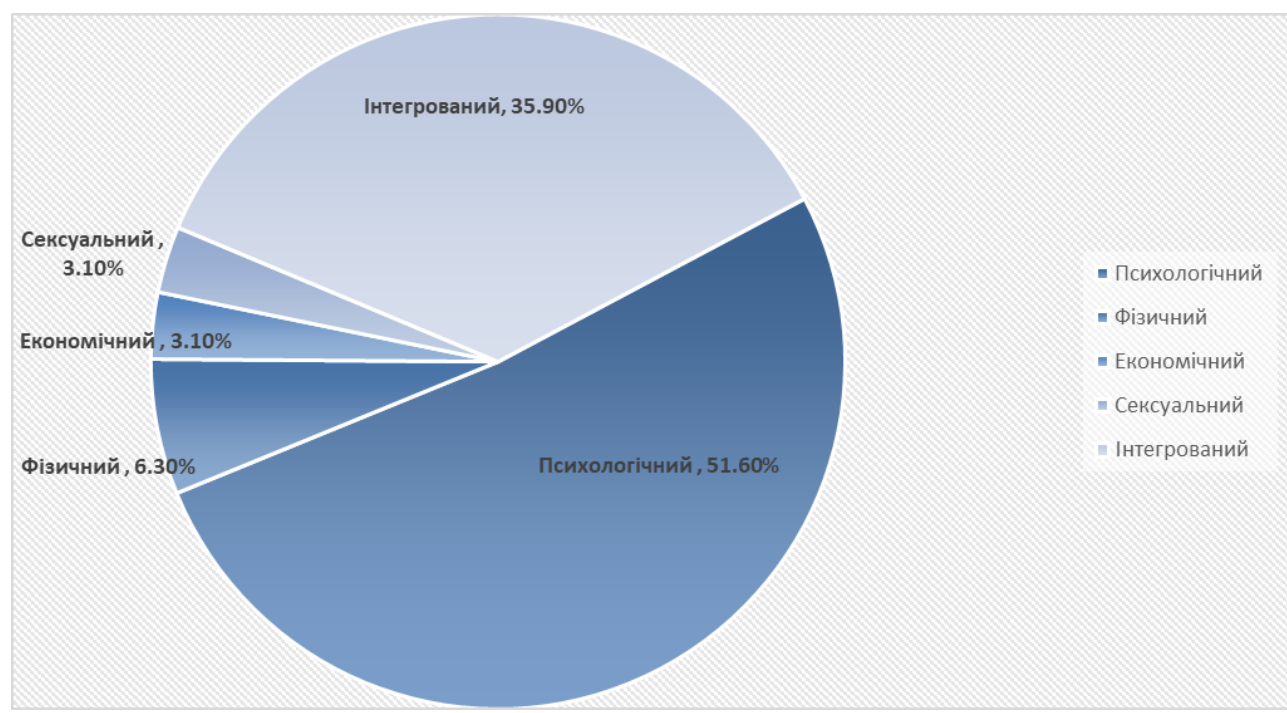

Рис. 1. Усвідомлення школярами проблеми булінгу в його домінантному спрямуванні

ральному приниженні, цькуванні та знущанні з боку однолітків.

Окрім інформаційно-змістового аспекту, важливою складовою вивчення проблеми булінгу $є$ питання структурно-позиційного розподілу. Під час конфліктної ситуації діти займають різні позиції. Одні з них, хто виявляє агресивне ставлення, є агресорами (або булерами) - вони переслідують та цькують жертву. Жертвами виступають діти, котрі знаходяться на більш слабкій позиції і посягають на статусний концепт булера. Вони відрізняються за фізичними даними, статусним рівнем та комунікативними вміннями. Зазвичай, ці якості, у них менше розвинені, ніж у булерів.

Зазвичай, булерами стають школяріприбічники культу сили, котрі нечутливі до страждань інших. Вони мають хорошу фізичну підготовку, але в повсякденному житті неврівноважені та імпульсивні, тому всі конфлік- ти вирішують за допомогою сили, бійок та баталій. Провідною тенденцією для них є потреба в самоактуалізації, яку вони задовольняють за рахунок знущання над слабшими дітьми. Застосовуючи фізичне чи психологічне насильство, вони реалізують свою здатність керувати іншими та управляти ситуацією, цим показуючи свою вищість над однолітками. Така поведінка - це поведінка диктаторів, для яких основним засобом досягнення очікуваного результату є терор з примушуванням слабких дітей до певних дій через залякування та актуалізацію почуття страху.

Протилежною стороною конфлікту виступає жжертва булінгу. Ї̈̈ дії є протилежними тим, які виявляє агресор. Зазвичай, такі школярі морально є більш слабкими, схильними до сором'язливості, тривожності, замкнутості та інших проблем комунікативного характеру. Вони мають гірші фізичні дані, іноді характе- 
рні фізичні вади (недоліки зовнішності, поганий зір, який доповнюється незграбними окулярами, непропорційну фігуру чи зріст). Часто до жертв булінгу належать діти, котрі мають нижчі матеріальні можливості, адже у шкільному середовищі це $\epsilon$ актуальним питанням. Приводом до цькування може бути також низька комунікативна компетентність та порушені соціальні навички - школярі недолюблюють замкнутих і дивакуватих однолітків. Не останнім пунктом є проблеми емоційної сфери - тривожні, нервозні, залякані та імпульсивні діти завжди будуть привертати увагу тих, хто любить продемонструвати свою сміливість у нерівному поєдинку [1; 3-6; 9].

Також у ситуації шкільного насилля виявляються треті ролі - це ролі спостерігачів. Вони прямо не беруть участі в акті агресії, оскільки самі побоюються опинитись на місці жертви. Більш сміливі з них стають на захист жертви, однак така ситуація відбувається лише у третині випадків (37,5\%; див. рис. 3$)$. Всі інші спостерігачі - це пасивна мовчазна опозиція або активна підтримка булера. Тому, у більшості ситуацій жертва залишається віч-на -віч з агресором.

Психологічні особливості сnостеріzаиів є досить різноманітними, як і їх поведінка. Одні з них мовчазно спостерігають за актами цькування і не поспішають приймати чиюсь сторону - вони вичікують і не намагаються конфліктувати з булером через побоювання опинитись на місці жертви. Інші активно зай- мають сторону булера і допомагають йому в акті насилля, підтримуючи репліками, глузуваннями чи фізично. Такі діти характеризуються підвищеним рівнем конформності, який зумовлює поведінку залежну від домінантного впливу. Окрім описаних двох $є$ ще й третя категорія, вчинки якої характеризуються гуманістичною спрямованістю та прагненням допомогти жертві у ситуації насилля.

Аналіз психологічних особливостей усіх учасників булінгу дає змогу стверджувати, що найбільш уразливою є позиція жертви. Результати проведеного анкетування дали змогу з'ясувати, що жертвами булінгу у різні періоди свого життя були 58 школярів із 128 (45,3 \%). Це вказує на те, що близько половини школярів хоча б один раз зазнавали цькувань і знущань з боку однолітків. Серед проявів булінгу спостерігається такий розподіл: фізична агресія (6,2 \%); словесні напади та знущання (43,8 \%); залякування (4,7 \%); відторгнення однолітками (15,6\%); приниження гідності перед класом з боку педагога (3,1\%); сексуальні нападки чи домагання $(4,7 \%)$, відбирання речей $(1,6 \%)$; усі різновиди $(15,6 \%)$ (див. Рис. 2).

Як бачимо за результатами діаграми, найчастіше стосовно учнів виявляють словесні напади та знущання (43,8 \%). Це свідчить про найбільшу розповсюдженість серед школярів психологічних форм булінгу. Найменше випадків стосується відбирання речей та інших матеріальних цінностей, що $є$ ознакою 


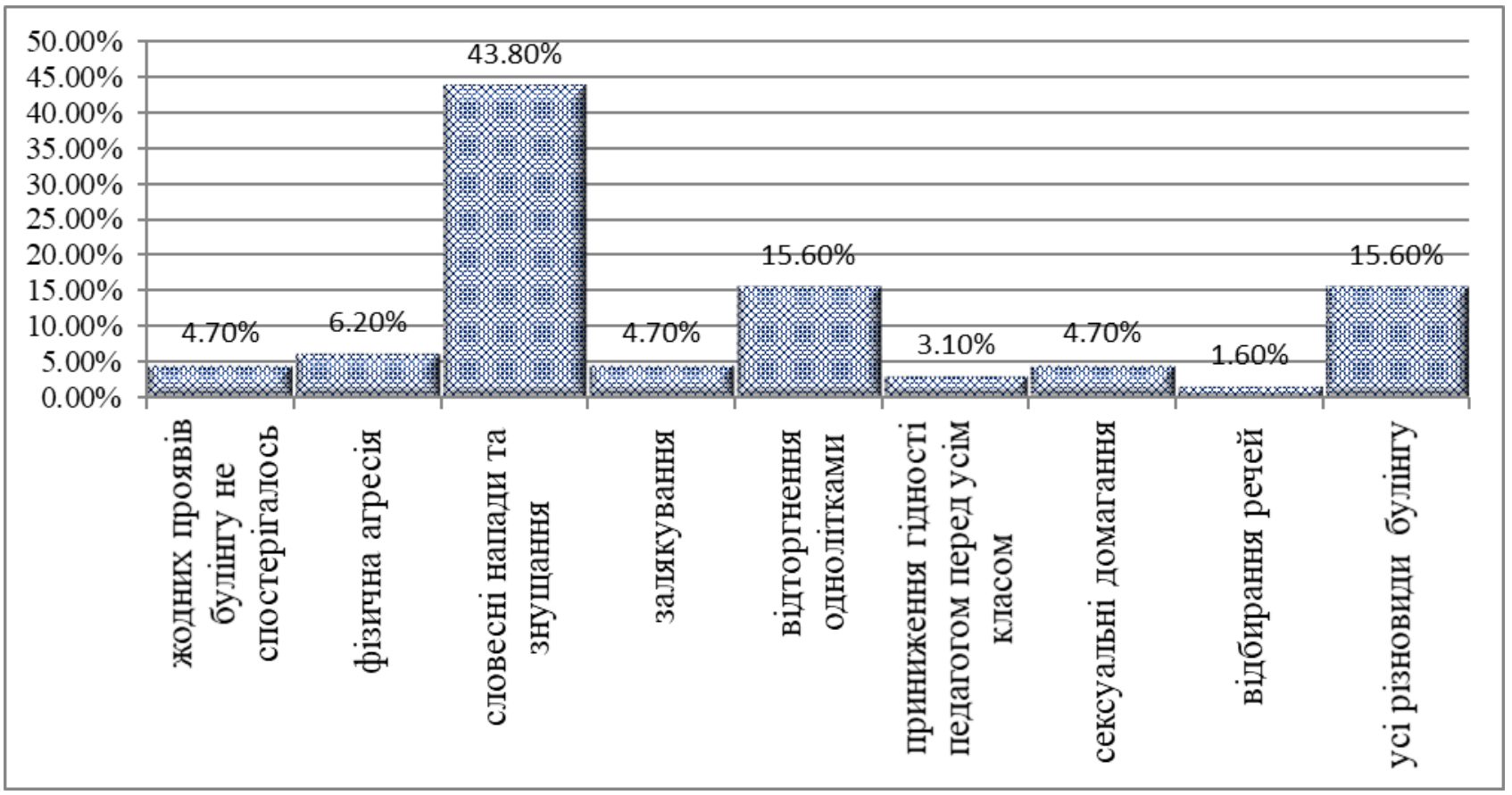

Рис. 2. Диференційний розподіл за формами та проявами булінгу серед дітей юнацького віку

економічного булінгу $(1,6 \%)$.

Результати анкетування продемонстрували те, що у ролі булерів-переслідувачів, переважно, виступали однолітки або старші діти (80,5\%). Дуже рідко інспіраторами булінгу були батько (4,9\%), інші родичі $(2,4 \%)$ або незнайомі люди у громадських місцях (12,2\%). Взагалі у вибірці не виявлено вказівок на те, що булінг здійснювали педагоги і матері.

Щодо емоційного ставлення до нападів і знущань, то юнаки і дівчата засвідчували на те, що в ситуації спрямованої агресії вони відчували різні емоції: образу, біль, ненависть до кривдника, бажання помститися, власну слабкість, зневіру, страх, інші реакції. Водночас, переважали образа $(32,8 \%)$, біль $(17,2 \%)$, зне- віра $(21,9 \%)$ та почуття власної слабкості $(12,5 \%)$. Найменше у конфліктній ситуації проявлялись спокійні реакції (1,6\%), а також, як не дивно, страх $(1,6 \%)$, що підтверджує гіпотезу про функціонування страху як передчуття негативної події і його зниження у момент іiі здійснення.

Досвід ефективної комунікації показує, що для кожної кризової ситуації необхідна підтримка з боку значимих інших людей. У становищі булінгу, в якому дитина зазнає деструктивного впливу, дорослі та однолітки мають не лише усвідомлювати, що дитині потрібна допомога, а й уміти реально ії надавати. Водночас, результати опитування показують, що не завжди така підтримка наявна. Про 
це свідчать відповіді на запитання: «Хто захищав вас у ситуаціях булінгу?», які учні розподілили так: друзі (37,5\%); батьки $(24,4 \%)$, інші родичі $(2,4 \%)$, педагоги $(4,4 \%)$, не отримували допомоги взагалі або намагались захистити себе самостійно $(28,9 \%)$. Критичним у цій ситуації є те, що діти майже не отримують захисту від педагогів, котрі насамперед мали б допомогти їм як жертвам булінгу, позаяк постійно знаходяться поряд із дітьми і мають помічати такі випадки. Водночас, доля їх сприяння - всього 4,4\%, що відображено на діагра-

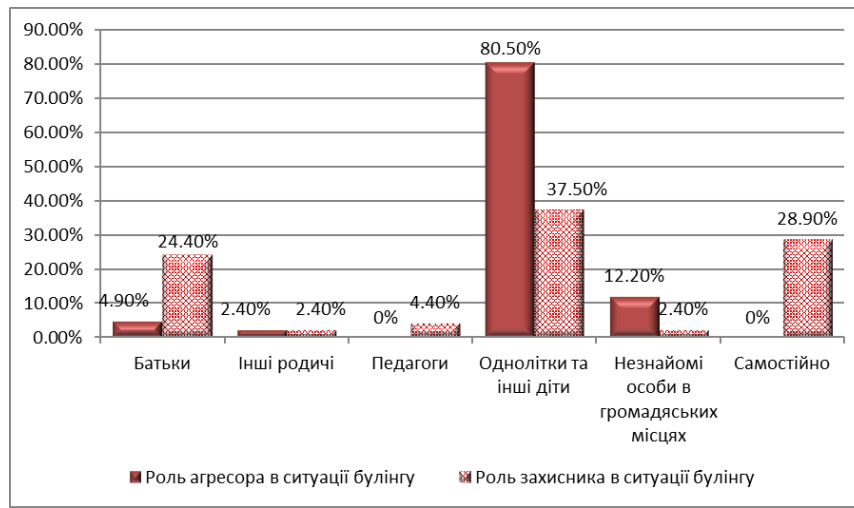

Рис. 3. Роль людського фактора у формуванні та усуненні проблеми булінгу

мі 3, за результатами якої проаналізовано роль людського фактора в усуненні проблеми булінгу:

Дані рисунку 3 вказують на те, що головну роль у ситуації булінгу відіграють однолітки, які виступають як булерамипереслідувачами (80,5\%), так захисниками (37,5\%). Несприятливим фактором $\epsilon$ те, що третина дітей $(28,9 \%)$ захищає себе самостійно, оскільки допомоги їм сподіватись немає від кого. Чверті дітей допомагають батьки $(24,4 \%)$. I зовсім мало сенсу сподіватись на допомогу з боку інших родичів $(2,4 \%)$, педагогів $(4,4 \%)$ або незнайомих людей у громадських місцях (2,4\%).

Завершальним етапом дослідження стало вивчення поведінки дітей, котрі виконували роль агресора у ситуації булінгу. Це ті, котрі відповіли ствердно на запитання «Чи ви самі коли-небудь принижували інших?». Серед них $-42,2 \%$ школярів. Провокувало учнів на таке ставлення слабкість товариша $(9,4 \%)$; його неадекватна поведінка $(25,0 \%)$; агресивне ставлення до них (40,6\%); агресивне ставлення до їх друзів $(9,4 \%)$ та бажання самоствердитись (15,6\%). Як бачимо, найбільш провокуючими факторами є агресивне ставлення до потенційного переслідника (40,6\%) та неадекватна поведінка жертви булінгу $(25,0 \%)$, тому саме ці якості потребують посиленої психологічної корекції.

Висновки. Очевидно, що ефективна комунікація є важливим та невід'ємним аспектом нашого життя. Те, що на сьогодні Україна на 4 місці в Свропі щодо поширення проблеми булінгу, а в школах 45,3\% дітей були жертвами булінгу і 42,2\% самі ж його провокували, свідчить про те, що проблема булінгу є назрілою та актуальною. Детальний аналіз показує, що у школярів не сформовані навички конструктивної взаємодії та вміння реагувати в кризових ситуаціях. Виходячи 3 того, що самостійно ці навички не формуються, а в ук- 
раїнських школах не введено дисциплін 3 психології комунікації, пропонуємо додати до шкільної програми обов'язковий курс, орієнтований на формування комунікативних навичок у різних сферах життя та діяльності, що стосуються спілкування з однолітками, ділової комунікації з вчителями та іншими дорослими, сімейного спілкування у родині, а також конструктивних вмінь будувати комунікацію у кризових ситуаціях, використовуючи норм етичної взаємодії.

\section{Подальші перспективи дослідження} полягають у розробленні програм психологічної роботи з протидії булінгу.

\section{Перелік використаних джерел:}

1. Вольнова Л.М. Профілактика девіантної поведінки підлітків : навч.-метод. посібник / Л.М. Вольнова. - К., 2016. Ч. 1. Теоретична частина. у 2-х ч. 2-ге вид. - 188 c.

2. Гончарук Н.М. Особливості формування психологічних захисних механізмів у ситуаціях спілкування в дітей підліткового віку / Н.М. Гончарук, Л.А. Онуфрієва // PSYCHOLOGICAL JOURNAL No 6 (16) 2018. P.52 -66. DOI (Issue): https://doi.org/10.31108/1.2018.6.16.4

3. Губко А.А. Шкільний булінг як соціальнопсихологічний феномен / А.А. Губко // Вісник Чернігівського національного педагогічного університету. Сер. : Психологічні науки. 2013. Вип. 114. С. 46-50.

4. Лейн Д.А. Школьная травля (буллинг). Детская и подростковая психотерапия / под ред. Д. Лейна, Э. Миллера. Санкт-Петербург : Питер, 2001. С. 240-274.

5. Найдьонова Л.А. Кібер-булінг або агресія в інтернеті: способи розпізнання і захист дитини : метод. Рекоменд / Л.А. Найдьонова. - Серія: На допомогу вчителю. Вип. 4. К., 2011.34 с.
6. Сидорук I. Булінг як актуальна соціально-педагогічна проблема / I. Сидорук // Науковий вісник Східноєвропейського національного університету імені Лесі Українки. Педагогічні науки. 2015. № 1. С. 169-173.

7. Про освіту : закон України. Відомості Верховної Ради. 2017. № 38-39. Ст. 380. С. 5.

8. Про внесення змін до деяких законодавчих актів України щодо протидії булінгу (цькуванню) : закон України. Офіційний вісник України. 2019. № 8. Ст. 255. С. 9. 9. Шевченко О.О. Що таке булінг? Профілактика виникнення та подолання проявів булінгу в дитячому середовищі (тренінгові заняття для керівників МО класних керівників) / О.О. Шевченко // Виховна робота в школі. Х. : Основа, 2010. №6. С. 48-55.

10. Bullying : an official website of the United States government. Stopbullying. September 28, 2017. URL : https://www.stopbullying.gov/what-is-bullying/index.html. 11. Randall P. Bullying in Adulthood: Assessing the Bullies and Their Victims. Florence, KY, USA: BrunnerRoutledge, 2001. $10 \mathrm{p}$.

12. Perillo M. Bullying in science: let's face the problem : [Електронний ресурс] ASCB. March 16, 2018. URL : https://www.ascb.org/ascb-post/careers/bullying-sciencelets-face-problem/

13. Bern E. Games People Play: The Psychology of Human Relationships / E. Bern. - New York : Grove Press, 1964.

14. Freud A. Theory and Practice in Child Psychoanalysis / [edited by G. Hall, F.Hivernel, S. Morgan]. - London : Karnac Books, 2009. - 224 p.

\section{References (Transliteration):}

1. Vol'nova L.M. Profilaktyka deviantnoi' povedinky pidlitkiv : navch.-metod. posibnyk / L.M. Vol'nova. - K., 2016. Ch. 1. Teoretychna chastyna. u 2-h ch. 2-ge vyd. $188 \mathrm{~s}$.

2. Goncharuk N.M. Osoblyvosti formuvannja psyhologichnyh zahysnyh mehanizmiv u sytuacijah spilkuvannja v ditej pidlitkovogo viku / N.M. Goncharuk, L.A. Onufrijeva // PSYCHOLOGICAL JOURNAL No 6 
(16) 2018. R.52-66. DOI (Issue): https:// doi.org/10.31108/1.2018.6.16.4

3. Gubko A.A. Shkil'nyj buling jak social'nopsyhologichnyj fenomen / A.A. Gubko // Visnyk Chernigivs'kogo nacional'nogo pedagogichnogo universytetu. Ser. : Psyhologichni nauky. 2013. Vyp. 114. S. $46-50$.

4. Lejn D.A. Shkol'naja travlja (bulling). Detskaja i podrostkovaja psihoterapija / pod red. D. Lejna, Je. Millera. Sankt-Peterburg : Piter, 2001. S. 240-274.

5. Najd'onova L.A. Kiber-buling abo agresija v interneti: sposoby rozpiznannja i zahyst dytyny : metod. Rekomend / L.A. Najd'onova. - Serija: Na dopomogu vchytelju. Vyp. 4. K., 2011.34 s.

6. Sydoruk I. Buling jak aktual'na social'no-pedagogichna problema / I. Sydoruk // Naukovyj visnyk Shidnojevropejs'kogo nacional'nogo universytetu imeni Lesi Ukrai'nky. Pedagogichni nauky. 2015. № 1. S. 169-173.

7. Pro osvitu : zakon Ukrai'ny. Vidomosti Verhovnoi' Rady. 2017. № 38-39. St. 380. S. 5.

8. Pro vnesennja zmin do dejakyh zakonodavchyh aktiv Ukrai'ny shhodo protydii' bulingu (c'kuvannju) : zakon Ukrai'ny. Oficijnyj visnyk Ukrai'ny. 2019. № 8. St. 255. S. 9.

9. Shevchenko O.O. Shho take buling? Profilaktyka vynyknennja ta podolannja projaviv bulingu v dytjachomu seredovyshhi (treningovi zanjattja dlja kerivnykiv MO klasnyh kerivnykiv) / O.O. Shevchenko // Vyhovna robota v shkoli. H. : Osnova, 2010. №6. S. 48-55.

10. Bullying : an official website of the United States government. Stopbullying. September 28, 2017. URL : https:/www.stopbullying.gov/what-is-bullying/index.html.

11. Randall P. Bullying in Adulthood: Assessing the Bullies and Their Victims. Florence, KY, USA: BrunnerRoutledge, 2001. 10 p.

12. Perillo M. Bullying in science: let's face the problem : [Elektronnyj resurs] ASCB. March 16, 2018. URL : https:// www.ascb.org/ascb-post/careers/bullying-science-lets-faceproblem/

13. Bern E. Games People Play: The Psychology of Human
Relationships / E. Bern. - New York : Grove Press, 1964. 14. Freud A. Theory and Practice in Child Psychoanalysis / [edited by G. Hall, F.Hivernel, S. Morgan]. - London : Karnac Books, 2009. - 224 r.

\section{Honcharuk Nataliia}

Ph. D. Psychological Sciences, Assistant Professor, Assistant Professor of the Department of General and Practical Psychology, Kamyanets-Podilsky Ivan Ohienko National University, Kamianets-Podilskyi (Ukraine)

\section{Onufriieva Liana}

Ph. D. in Psychological Sciences, Assistant Professor, Professor of the Department of General and Applied Psychology, Head of the Department of General and Applied Psychology, Kamianets-Podilskyi National Ivan Ohiienko University, Kamianets-Podilskyi (Ukraine)

\section{PSYCHOLOGICAL PRINCIPLES OF BULLYING AT JUVENILE AGE}

\section{ABSTRACT}

The article deals with the problem of bullying among the senior pupils. The urgency of the problem is confirmed by statistical data, because today Ukraine is on the 4th place in Europe with regard to the propagation of the problem of bullying. At schools $45.3 \%$ of children were victims of bullying and $42.2 \%$ of children provoked it themselves, testifying that the problem of the bullying is important and relevant. The approaches to explain this phenomenon are described by the authors as a psychological phenomenon. The forms and types of bullying are singled out. The main features of bullying as a system concept, covering psychological, physical and other types of directed aggressive influence are revealed. During the empirical study, characteristics have been 
identified that make it possible to study the various aspects of the psychological problem in question. In particular, the information-content and structural-positional aspects of it were worked out and the necessity of developing a differentiated approach to overcoming bullying as a diversified form of child abuse was proved.

According to the results of the research, the attention is focused at the most urgent issues, which are the task of enhanced psychological and pedagogical control over the behavior and conditions of schoolchildren development, the formation of skills of constructive communication among peers and child-parent interaction in crisis situations.

The experience of effective communication demonstrates that the support of other significant people is needed for each crisis situation. It is revealed that in the situation of bullying where the child suffers from destructive influence, adults and peers should not only realize that the child needs a help, but they also should be able to provide it really. At the same time, the results of the survey state that this support is not always available. It is shown that the critical point in this situation is that children almost do not receive protection from teachers who should first of all help them as victims of bullying because they are constantly in contact with children and should notice such cases. The detailed analysis shows that schoolchildren haven't developed skills of constructive interaction and ability to react in crisis situations. Based on the fact that these skills are not formed on their own, and in Ukrainian schools there are no disciplines in the psychology of communication, it should be advisable to add to the school curriculum a compulsory course aimed at the formation of communicative skills in various spheres of life and activities relating to communication with peers, business communication with teachers and other adults, family communication in the family, as well as constructive skills to build communication in crisis situations, using ethical norms of interaction.

Keywords: bullying, aggressor, bullying victim, forms of bullying.

\section{Гончарук Наталья Николаевна}

Кандидат психологических наук, доиент, дочент кафедры общей и практической психологии, КаменеиПодольский национальньій университет имени Ивана Огиенко, г. Каменеи-Подольский (Украина)

\section{Онуфриева Лиана Анатольевна}

Кандидат психологических наук, дочент, профессор кафедры общей и практической психологии, заведующий кафедры общей и практической психологии, Каменеи-Подольский национальный университет имени Ивана Огиенко, г. Каменец-Подольский (Украина)

\section{ПСИХОЛОГИЧЕСКИЕ ОСНОВЫ БУЛЛИНГА В ЮНОШЕСКОМ BO3PACTE}

Аннотация. В статье освещена проблема буллинга в среде старшеклассников. Отмечено, что эффективная коммуникация является важным и неотъемлемым аспектом жизни школьников. Актуальность проблемы подтверждается статистическими данными, ведь на сегодня Украина на 4 месте в Европе 
по распространению проблемы буллинга, а в школах 45,3\% детей были жертвами буллинга и 42,2\% сами его провоцировали, это свидетельствует о том, что проблема буллинга является назревшей и актуальной. Авторами описаны подходы к объяснению этого явления как психологического феномена. Выделены формы и разновидности буллинга. Раскрыты основные его характеристики как системного концепта, который охватывает психологическое, физическое и другие виды направленного агрессивного воздействия. Во время эмпирического исследования определены характеристики, которые делают возможным изучить различные стороны указанной психологической проблемы. В частности, обработаны информационно-содержательный и структурнопозиционный её аспекты и доказана необходимость разработки дифференцированного подхода к преодолению буллинга как разноплановой формы детского насилия.

По результатам исследования акцентировано внимание на наиболее актуальных вопросах, как задачи усиленного психологопедагогического контроля за поведением и условиями развития школьников, формирование навыков конструктивной коммуникации в среде сверстников и детско-родительского взаимодействия в кризисных ситуациях. Детальный анализ показывает, что у школьников не сформированы навыки конструктивного взаимодействия и умение реагировать в кризисных ситуациях. Исходя из того, что само- стоятельно эти навыки не формируются, а в украинских школах не введены дисциплины по психологии коммуникации, целесообразно было бы ввести в школьную программу обязательный курс, ориентированный на формирование коммуникативных навыков в различных сферах жизни и деятельности, касающиеся общения со сверстниками, деловой коммуникации с учителями и другими взрослыми, семейного общения в семье, а также конструктивных умений строить коммуникацию в кризисных ситуациях, используя нормы этического взаимодействия.

Ключевые слова: буллинг, буллер, агрессор, жертва буллинга, форма буллинга.

Дата отримання статті: 02.03.2019 Дата рекомендації до друку: 12.03.2019 Дата оприлюднення: 17.04.2019 